\title{
Diel cycles of sulphate reduction rates in sediments of a Zostera marina bed (Denmark)
}

\author{
Vibeke Blaabjerg ${ }^{1}$, Kim N. Mouritsen ${ }^{2}$, Kai Finster ${ }^{1, *}$ \\ 'Department of Microbial Ecology and ${ }^{2}$ Department of Marine Ecology, Institute of Biological Sciences, \\ University of Aarhus, DK-8000 Aarhus, Denmark
}

\begin{abstract}
Sulphate reduction was investigated over $24 \mathrm{~h}$ cycles in Zostera marina-bearing sediments. The experiments were carried out at the beginning (April) and end (August) of the growing season of the eelgrass. The sulphate reduction rates were 3 times higher in August $\left(\sim 90 \mathrm{mmol} \mathrm{SO}{ }_{4}^{2-} \mathrm{m}^{-2}\right.$ $\mathrm{d}^{-1}$ ) than in April. In both periods, the sulphate reduction rates were significantly higher in the light than in the dark. The stimulation in the light may be due to increased root exudation of organic matter related to photosynthetic activity. The exuded organic carbon accounted for approximately 2 to $4 \%$ of the total amount of carbon fixed by the plants. The sulphate reduction rates responded rapidly to shifts from dark to light and vice versa, indicating the presence of a limited pool of labile organic matter in the sediment. A positive correlation between sulphate reduction rates and root+rhizome biomass was observed in April and August during the daytime and in August but not April in the dark.
\end{abstract}

KEY WORDS: Light-stimulated sulphate reduction $\cdot$ Marine $\cdot$ Anaerobic $\cdot$ Seagrasses

\section{INTRODUCTION}

Seagrass meadows are highly productive environments (reviewed in Pollard et al. 1993) and, consequently, seagrasses are important sources of organic matter in coastal marine ecosystems (Thayer et al. 1975, McRoy \& McMillan 1977). They can stimulate both aerobic and anaerobic mineralisation processes (Sand-Jensen et al. 1982, Smith et al. 1984, Blackburn et al. 1994, Holmer \& Nielsen 1996, Isaksen \& Finster 1996, Welsh et al. 1996) and influence bacterial productivity in the sediment (Moriarty et al. 1986, 1990, Pollard \& Moriarty 1991, López et al. 1995). Recent investigations have shown that living seagrasses release dissolved organic carbon (DOC) to the environment (Penhale \& Smith 1977, Wetzel \& Penhale 1979, Moriarty et al. 1986), and a close interaction between the plants and the microbial community of the rhizosphere has been suggested (Oremland \& Taylor 1977, Koepfler et al. 1993, Glazebrook et al. 1996). The release of photosynthates in the light may lead to a short-term stimulation of bacterial processes, recognisable as diel

·Addressee for correspondence. E-mail: kai@bio.aau.dk cycles. Diel cycles of bacterial growth and nitrogen fixation have previously been observed in the sediments of seagrass beds (Pollard \& Moriarty 1991, Welsh et al. 1997). Also, stimulation of sulphate reduction in the light has been reported from tropical seagrasses (Moriarty et al. 1985, Pollard \& Moriarty 1991, Blackburn et al. 1994). Recently, diel cycles of sulphate reduction rates were documented in hypersaline microbial mats (Fründ \& Cohen 1992, Jørgensen 1994). Fründ \& Cohen speculated upon a combination of temperature increase and light-dependent excretion of photosynthates, while Jørgensen, after having correlated rates and temperature, argued for the predominance of a temperature dependent stimulation.

Sulphate reduction is quantitatively the most important process of organic matter mineralisation in anoxic coastal marine sediments (Jørgensen 1982, Howarth 1984, King 1988, Canfield 1992), and it is consequently of great interest to what extent this process is affected by periodic events such as light-dependent exudation of organic matter into the rhizosphere. Neglecting these events may lead to an underestimation of the contribution of sulphate reduction to organic matter mineralisation in macrophyte communities. 

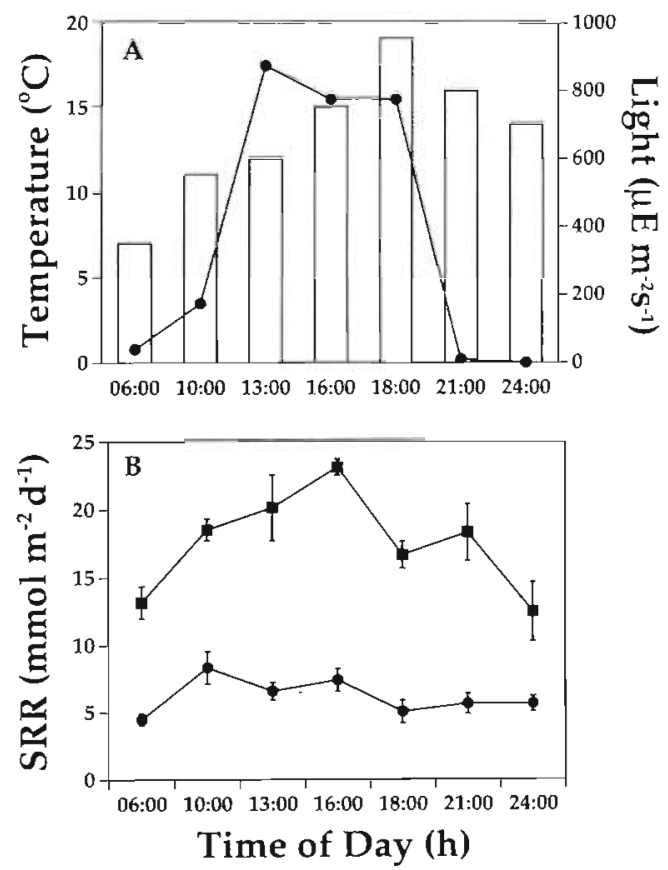

Fig. 1. (A) Water temperature (bars) and light fluxes ( $\bullet$ ) at the study site, 24 April 1995. (B) Mean sulphate reduction rates (SRR) as a function of time of day (24 April 1995): (-) 0 to $6 \mathrm{~cm}$ horizon; $(\bullet) 6$ to $12 \mathrm{~cm}$ horizon. Error bars show $\pm \mathrm{SE}$ $(\mathrm{n}=5)$. Cores were incubated for $1 \mathrm{~h}$ in the dark at in situ temperature

The aim of this study was to follow, with high temporal resolution, sulphate reduction in sediments under a meadow of Zostera marina. Furthermore, we wanted to investigate whether sulphate reduction rates were correlated with the quantity of roots and rhizomes present in the sediment.

\section{MATERIAL AND METHODS}

Study site and sampling procedure. The sampling site was located in Løgstor Bredning, Limfjorden, Denmark (56 $\left.58^{\circ} \mathrm{N}, 9^{\circ} 15^{\prime} \mathrm{E}\right)$. It consisted of areas covered by the eelgrass Zostera marina as well as macrophyte free areas. The water level varied between 15 and $60 \mathrm{~cm}$ due to wind-induced variation throughout our investigation period. The eelgrass patch chosen for sampling was about $2 \times 7 \mathrm{~m}$ and was situated $50 \mathrm{~m}$ from the shore. Shoot density was approximately $800 \mathrm{~m}^{-2}$ in April and $2000 \mathrm{~m}^{-2}$ in August (Hansen pers. comm.).

Experiments were carried out on 24 April and 16 August 1995. In April, the water temperature varied between 7 and $19^{\circ} \mathrm{C}$, while in August it varied only slightly between 20 and $22^{\circ} \mathrm{C}$ (Figs. $1 \mathrm{~A} \& 2 \mathrm{~A}$ ). Salinity was $25 \%$ in both April and August. Both in April and in
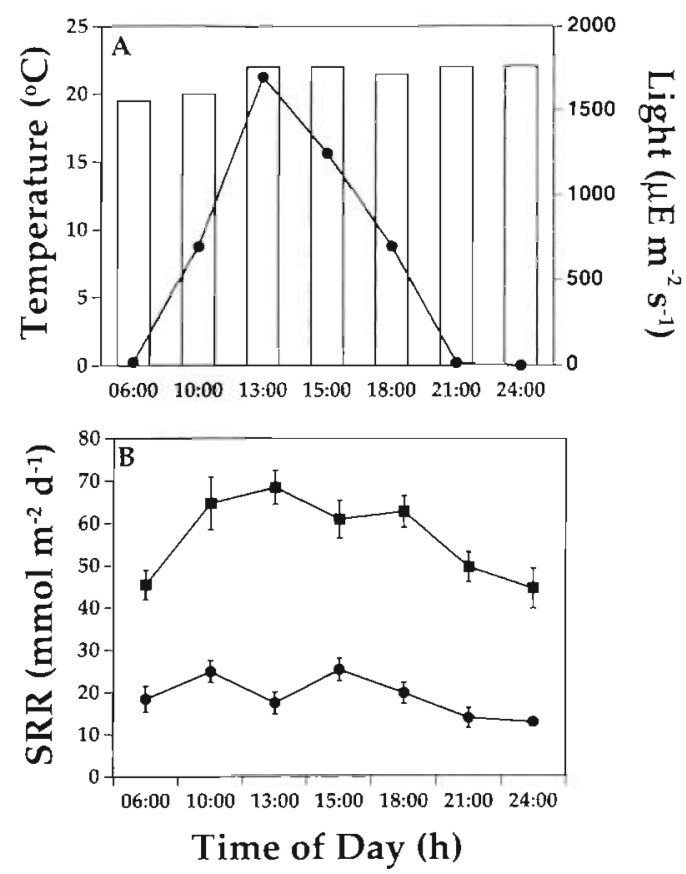

Fig. 2. (A) Water temperature (bars) and light fluxes $(\bullet$ ) at the study site, 16 August 1995. (B) Mean sulphate reduction rates (SRR) as a function of time of day (16 August 1995): ( 0 ) to $6 \mathrm{~cm}$ horizon $(\bullet) 6$ to $12 \mathrm{~cm}$ horizon. Error bars show $\pm \mathrm{SE}$ $(\mathrm{n}=5)$. Cores were incubated for $1 \mathrm{~h}$ in the dark at in situ temperature

August, the highest light intensities were measured around noon above the eelgrass meadow. They were 900 and $1600 \mu \mathrm{E} \mathrm{m}^{-2} \mathrm{~s}^{-1}$, respectively (Figs. 1A \& 2A). The April light fluxes were measured with a planar sensor, while the August fluxes were measured with a spherical sensor. A comparison of the sensors showed that values obtained by the planar sensor should be multiplied by 2 to give the same light flux values as those measured with the spherical sensor under identical conditions.

Sediment cores were taken in the central part of a Zostera marina patch by gently pushing Plexiglas tubes ( $5.2 \mathrm{~cm}$ inner diameter) into the sediment. Care was taken not to introduce leaves into the sediment. The tubes were sealed with a rubber stopper and pulled out of the sediment. Cores (5 replicates) were collected at 2 to $4 \mathrm{~h}$ intervals except for one $6 \mathrm{~h}$ period during the night. They were carried to the shore and processed within 30 min.

Sulphate reduction rate measurements. Radiolabeled sulphate ( 5 to $10 \mu \mathrm{l}, 100 \mathrm{MBq} \mathrm{ml}^{-1}$; Isotope Laboratorie, Riso, Roskilde, Denmark) diluted in a $27 \%$ $\mathrm{NaCl}$ solution was injected through silicone rubberfilled injection ports at the start of the incubation, giving an average activity of 65 to $130 \mathrm{mCi} \mathrm{cm}^{-3}$. The injection ports were arranged in 2 vertical rows. The 
rows were separated by an angle of $90^{\circ}$ and the distance between the injection ports within each row was $1 \mathrm{~cm}$. After injection of the tracer, the cores were submerged in a sea water filled container and incubated in the dark at in situ temperature for $1 \mathrm{~h}$. At the end of the incubation the sediment was extruded from the tubes and cut into $1 \mathrm{~cm}$ (from 0 to $6 \mathrm{~cm}$ depth) or $2 \mathrm{~cm}$ (from 6 to $12 \mathrm{~cm}$ depth) thick slices. The slices were transferred into $50 \mathrm{ml}$ screw-capped plastic centrifuge tubes containing 5 or $10 \mathrm{ml}$ of a $20 \%(\mathrm{w} / \mathrm{w})$ zinc acetate solution. Zinc acetate inhibits further sulphate reduction and preserves sulphide as ZnS. The tubes were sealed, vigorously shaken and then stored at $5^{\circ} \mathrm{C}$ until further processing. Prior to $\mathrm{H}_{2}{ }^{35} \mathrm{~S}$ and ${ }^{35} \mathrm{SO}_{4}{ }^{2-}$ activity measurements, roots and rhizomes were removed from the samples. They were rinsed in sea water and dried at $105^{\circ} \mathrm{C}$ for $24 \mathrm{~h}$ for biomass dry weight determination.

The formation of $\mathrm{H}_{2}{ }^{35} \mathrm{~S}$ was determined by the 1-step $\mathrm{Cr}^{2+}$ distillation method (Fossing \& Jørgensen 1989). Sulphate reduction rates were calculated according to Fossing \& Jørgensen (1989).

Sulphate in pore water. Pore water was obtained by centrifugation of $\mathrm{Zn}$-acetate-preserved sediment samples taken during the radio-tracer experiment. Sulphate was determined by suppressed ion chromatography with a Sykam (Gilching, Germany) ionchromatography system. The stainless-steel column ( $4 \mathrm{~mm}$ by $125 \mathrm{~mm}$; LCA A09, Sykam) was kept at $60^{\circ} \mathrm{C}$. The eluent contained $\mathrm{Na}_{2} \mathrm{CO}_{3}$ (7.5 mM), ethanol (5\%, vol/vol), and 4-hydroxy-benzonitril (50 $\mathrm{mg} \mathrm{l}^{-1}$ ). The flow rate was $2 \mathrm{ml} \mathrm{min} \mathrm{m}^{-1}$ and the analysis time was 5 min.

Statistical analysis. All statistical tests were carried out using SPSS (Norusis 1993). Prior to main parametric analysis, assumptions of normality and homogeneity of variance were assured on either untransformed or ln-transformed data. Sum of squares and df associated with a non-significant 2-way interaction (the MANOVA, see below) were included in the residual variance of the subsequent reduced analysis. Statistical analysis was applied on data obtained from the 0 to $6 \mathrm{~cm}$ horizon only.

\section{RESULTS}

\section{Temporal variation in sulphate reduction rates}

In both April and August, the sulphate reduction rates measured in the sediment of the Zostera marina bed showed a significant diel cycle (Figs. $1 \mathrm{~B} \& 2 \mathrm{~B}$ ) (1-way ANOVA; April: $F_{6,32}=5.03, \mathrm{p}<0.002$; August: $F_{6,34}=6.23, \mathrm{p}<0.001$ ). This pattern was especially pronounced in the upper $6 \mathrm{~cm}$ of the sediment, where the major part $(80 \%)$ of the root and rhizome biomass was located. In April, the sulphate reduction rates $(0$ to $6 \mathrm{~cm}$ ) increased from about $13 \mathrm{mmol} \mathrm{SO}_{4}{ }^{2-} \mathrm{m}^{-2} \mathrm{~d}^{-1}$ during the night (06:00 and 24:00 h) to about $22 \mathrm{mmol}$ $\mathrm{SO}_{4}{ }^{2-} \mathrm{m}^{-2} \mathrm{~d}^{-1}$ in the afternoon (15:00 h). In August, sulphate reduction rates increased from approximately $45 \mathrm{mmol} \mathrm{SO}_{4}^{2-} \mathrm{m}^{-2} \mathrm{~d}^{-1}$ at night to the maximal value of $68.5 \mathrm{mmol} \mathrm{SO}_{4}{ }^{2-} \mathrm{m}^{-2} \mathrm{~d}^{-1}$ at 13:00 h. In both April and August, the sulphate reduction rates measured in the 6 to $12 \mathrm{~cm}$ horizon were considerably lower than in the upper $6 \mathrm{~cm}$ of the sediment (Figs. $1 \mathrm{~B} \& 2 \mathrm{~B}$ )

A statistical analysis of sulphate reduction rates measured during darkness (06:00 and 24:00 h) and in light (April: 13:00 and 16:00 h; August: 10:00 and 13:00 h) revealed no significant difference between cores collected in light or in dark for either April or August (Student's $t$-test, $t_{8}<1.24, \mathrm{p}>0.25$ ). Hence, the collected cores were pooled into daytime cores and nighttime cores for further analysis. A subsequent analysis of variance evaluating the effect of light condition (daytime/nighttime samples) and period (April/August samples) on sulphate reduction rates showed a significant influence of both factors (MANOVA, light condition: $F_{1,37}=46.4, \mathrm{p}<0.001$; period: $F_{1,37}=359.5, \mathrm{p}<$ 0.001 ). LSD (least square difference) a posteriori tests evidenced that daytime sulphate reduction rates were significantly higher (approx. 1.6-fold) than nighttime values in both April and August $(p<0.01)$, and significantly higher (approx. 3.4-fold) in August than in April irrespective of light condition $(p<0.01)$.

\section{Relative influence of temperature and light intensity}

In April, water temperature and light intensity showed large diel variation, while in August water temperature was almost constant and only light intensities changed throughout the day (Figs. 1A \& 2A). Correlation analysis showed non-significant relationships between sulphate reduction rates and temperature (A.pril: $\mathrm{r}_{31}^{2}=0.06, \mathrm{p}=0.16$; August: $\mathrm{r}^{2}{ }_{33}=$ $0.01, p=0.54$ ), whereas sulphate reduction was significantly and positively related to light intensity (April: $\mathrm{r}_{31}^{2}=0.24, \mathrm{p}=0.004 ;$ August: $\mathrm{r}_{33}^{2}=0.45, \mathrm{p}<$ 0.001 ). This demonstrates that water temperature in contrast to light intensities had only minor influence on the observed diel variation in sulphate reduction rates.

\section{Relationship between sulphate reduction and root biomass}

The major part of the root and rhizome biomass of Zostera marina was found in the upper $6 \mathrm{~cm}$ of the sed- 

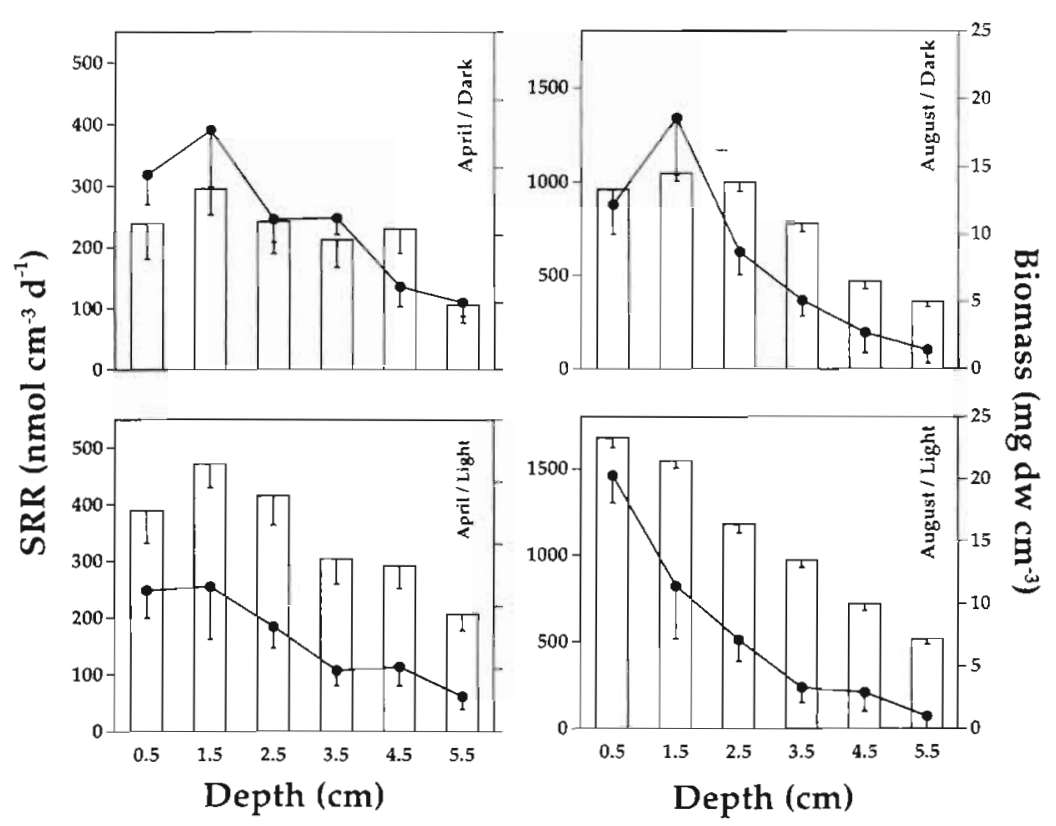

Fig. 3. Depth distribution of roots+rhizome biomass $(\bullet)$ and sulphate reduction rates (SRR) (bars) in April and in August in the light and in the dark. Calculated rates are based on data from 2 samplings in the light, including the time points when the highest SRR were observed, and 2 samplings in the dark; in total 10 cores for light and dark measurements, respectively. Error bars show $-\mathrm{SE}(\mathrm{n}=10)$

iment, where sulphate reduction rates were also highest (Fig. 3). In order to elucidate the influence of roots on sulphate reduction rates, corresponding mean values of sulphate reduction and root/rhizome biomass were obtained for each of the $1 \mathrm{~cm}$ depth intervals in the upper $6 \mathrm{~cm}$ of the sediment. Only the previously selected daytime and nighttime cores were analysed in this manner. Non-parametric statistics on the relationship between sulphate reduction and root biomass showed significant positive correlations during daytime (April: $\mathrm{r}_{\mathrm{S}}=0.89, \mathrm{df}=4, \mathrm{p}<0.002 ;$ August: $\mathrm{r}_{\mathrm{S}}=1.00$, $\mathrm{df}=4, \mathrm{p}<0.001$ ). However, in April this relationship disappeared in cores collected at night $\left(\mathrm{r}_{\mathrm{S}}=0.49\right.$, df $=$ $4, p=0.33$ ), whereas the positive relationship persisted in August samples taken at night $\left(\mathrm{r}_{\mathrm{S}}=0.94, \mathrm{df}=4, \mathrm{p}=\right.$ 0.005 ).

The positive relationship between sulphate reduction rates and root/rhizome biomass could be seen even within individual core samples. In August during daytime, when the highest sulphate reduction rates were measured, a significant positive correlation could be found in 7 of the 10 cores (1-tailed $\mathrm{r}_{\mathrm{S}}, \mathrm{df}=2$ to $4, \mathrm{p}<$ 0.04).

No significant difference in mean values of root/rhizome biomass could be demonstrated between April samples $\left(0.43 \mathrm{mg} \mathrm{cm}^{-3}\right)$ and August samples $(0.36 \mathrm{mg}$ $\mathrm{cm}^{-3}$ ) (Student's $t$-test, $t_{38}=1.30, \mathrm{p}=0.20$ ).

\section{DISCUSSION}

Sulphate reduction rates determined in the light were significantly higher than rates measured in the dark. Both in April and in August, sulphate reduction rates reached a maximum level at a relatively low light intensity and did not increase despite higher light intensities in the afternoon. Assuming that the increasing rates of sulphate reduction were directly fueled by leachates from the photosynthesising plants and that the flow of leachates was in equilibrium with the concentrations of dissolved organic matter in the roots, then these observations may indicate an upper limit for carbon assimilation by the plant. The light saturation point for Zostera marina photosynthesis is variable and seldom exceeds $150 \mu \mathrm{E} \mathrm{m} \mathrm{m}^{-2} \mathrm{~s}^{-1}$ (Dennison \& Alberte 1985, Zimmerman et al. 1994). This light flux is lower than the fluxes measured throughout most of the light period in our investigations and may explain why no further stimulation was observed at light intensities above the saturation point.

To explain the diel cycle observed in April and August in the light, we hypothesise that the stimulation in the light was mainly due to interactions between the photosynthesising macrophyte (Zostera marina) and the sulphate reducers in the rhizosphere. The statistically significant correlation of the dry weight of roots+rhizomes present in the sediment and the sulphate reduction rates supports this hypothesis. We interpret the rapid changes of the sulphate reduction rates as a response of sulphate reducers to shortterm releases of organic matter by the roots and rhizomes into the surrounding sediment. Similar observations of stimulated sulphate reduction in the middle of a light period were reported for tropical seagrass beds (Pollard \& Moriarty 1991, Blackburn et. al. 1994). A consideration of these relations is of great importance for investigations whose objective is to establish ecosystem budgets or/and in modelling.

The observation that sulphate redution rates were almost unaffected by temperature changes in April is somewhat surprising, as one would expect increasing rates with increasing temperature due to reaction kinetics. For instance, Jørgensen (1994) was able to explain changes in sulphate reduction rates in a hypersaline microbial mat exclusively by changes in temperature throughout a diel cycle, while changes in light intensities did not correlate with changes in sulphate reduction. 
One explanation for our observation may be related to the extreme weather conditions which prevailed prior to our investigation. The water (sediment) temperature was below $7^{\circ} \mathrm{C}$ for more than $4 \mathrm{mo}$. On the day of our rate measurements, the temperature exceeded $15^{\circ} \mathrm{C}$ for the first time. Thus the microbial community might still have been adapted to lower temperatures. Another explanation is that a small temperature effect was overshadowed by the light effect and therefore remained undetected in our investigation.

The changes of the sulphate reduction rates were most pronounced in the 0 to $6 \mathrm{~cm}$ depth interval where about $80 \%$ of the total root+rhizome biomass was located (Figs. 1B \& 2B). This finding clearly underlines the stimulating effect of roots and rhizomes on sulphate reduction. Similar observations were made by Isaksen \& Finster (1996), Pollard \& Moriarty (1991) and Holmer \& Nielsen (1996) in other sediments covered by seagrasses.

The increasing sulphate reduction rates observed in our investigation may be used to estimate the amount of DOC lost from Zostera marina roots and rhizomes into the rhizosphere. We make the following assumptions: (1) the stimulation of sulphate reduction was exclusively due to exudation of newly photosynthesised organic matter, (2) all material released is mineralised by the microbial community present in the rhizosphere, (3) the exudates immediately give rise to elevated sulphate reduction rates and (4) the amount of organic matter can be determined from the following equation:

$$
2 \mathrm{CH}_{2} \mathrm{O}+\mathrm{SO}_{4}^{2-} \rightarrow 2 \mathrm{HCO}_{3}^{-}+\mathrm{HS}^{-}+\mathrm{H}^{+}
$$

Thus, during our investigation in April and in August, organic carbon was during the daytime released at approximately 0.12 and $0.3 \mathrm{~g} \mathrm{C} \mathrm{m}^{-2} \mathrm{~d}^{-1}$, respectively. The net carbon fixation rates can be approximated from growth rates obtained by leaf-marking measurements (Borum pers. comm.). They were 3 and $15 \mathrm{~g} \mathrm{C} \mathrm{m}^{-2} \mathrm{~d}^{-1}$ in April and August, respectively. We can thus estimate a loss of organic carbon of approximately $4 \%$ and $2 \%$ of the net carbon assimulation in April and August, respectively. This is a conservative estimate as it neither considers the amount of released carbon assimilated by the bacteria nor includes mineralisation processes other than sulphate reduction. Our estimates are however in good agreement with the values obtained by Wetzel \& Penhale (1979) for $Z$. marina and other seagrasses. They incubated entire $Z$. marina plants with ${ }^{14} \mathrm{C}$ $\mathrm{NaHCO}_{3}$ and found that root-released carbon accounted for 1 to $3 \%$ of the carbon fixed in toto. Thalassia testudinum roots released about $8 \%$, while the excretion from Halodule wrightii Aschers $_{\text {was }} 0.7 \%$.

Little is known about the nature of the exudates. In most of the investigations, the exudates were not iden- tified but treated as DOC or categorised by molecular weight (Wetzel \& Penhale 1979, Moriarty et al. 1986). Jørgensen et al. (1981), however, showed that pore water concentrations of dissolved free amino acids (DFAA) in sediments of a Posidonia oceanica bed changed between light and dark. They suggest that the seagrass was the source of DFAA in the rhizosphere. It is thus not clear whether the exudates were directly available for sulphate reducers or if they were degraded by fermenting bacteria in the first place.

Despite the clear evidence our data give for a lightdependent diel variation of sulphate reduction rates, we are aware of methodological problems related to the procedures applied: (1) The determination of the sulphate reduction rates assumes a homogeneous distribution of the tracer in the sediment. The heterogeneity of the root environment requires an injection procedure which allows a more uniform distribution of the tracer. (2) The rapid decline of the sulphate reduction rates when going from light to dark indicates that the organic material released by the roots is exhausted quickly, Even though the time span from sample collection to rate determination was reduced by handling the samples on the spot, we may have underestimated the sulphate reduction rates.

\section{CONCLUSION}

Sulphate reduction in Zostera marina-bearing sediments seems to be influenced by the photosynthetic activity of the macrophyte, probably due to the loss of organic matter from the roots and rhizomes to the surrounding environment. The release increased sulphate reduction rates by more than $30 \%$. This finding underlines that light-induced changes, generally, have to be considered in budgets of organic matter mineralisation in macrophyte-bearing systems. The rapid degradation of the released material requires rapid handling of the samples and short incubation times. In addition, an appropriate injection procedure of the radiolabeled tracer has to be developed to account for the heterogeneity in the root zone.

Acknowledgements. This work is a contribution to the ELOISE programme (ELOISE No. 061) in the framework of the ROBUST project carried out under contract ENV4-CT960218. V.B. acknowledges support by the Centre for Strategic Environmental Research in Marine Areas' grant no. 4.15

\section{LITERATURE CITED}

Blackburn TH, Nedwell DB, Wiebe WJ (1994) Active mineral cycling in a Jamaican seagrass sediment. Mar Ecol Prog Ser 110:233-239

Canfield DE (1992) Organic matter oxidation in marine 
sediments. In: Wollast $R$ (ed) Interaction of $C, N, P$, and $\mathrm{S}$ biogeochemical cycles. Springer-Verlag, New York, p 333-363

Dennison WC, Alberte R (1985) Role of daily light period in the distribution of Zostera marina (eelgrass). Mar Ecol Prog Ser 25:51-61

Fossing $H_{1}$ Jargensen BB (1989) Measurement of bacterial sulfate reduction in sediments: evaluation of a single-step chromium reduction method. Biogeochemistry 8:205-222

Frund C, Cohen Y (1992) Diurnal cycles of sulfate reduction under oxic conditions in cyanobacterial mats. Appl Environ Microbiol 58:70-77

Glazebrook PW, Moriarty DJW, Hayward AC, MacRae IC (1996) Seasonal changes in numbers and the location of a particular bacterial strain Alteromonas sp. in seagrass sediments. Microb Ecol 31:1-13

Holmer M, Nielsen SL (1996) Sediment sulfur dynamics related to biomass-density patterns in Zostera marina (eelgrass) beds. Mar Ecol Prog Ser 146:163-171

Howarth RW (1984) The ecological significance of sulfur in the energy dynamics of salt marsh and coastal marine sediments. Biogeochemistry 1:5-27

Isaksen $M_{1}$. Finster K (1996) Sulphate reduction in the root zone of the seagrass Zostera noltii on the intertidal flats of a coastal lagoon (Arcachon, France). Mar Ecol Prog Ser 137:187-194

Jergensen BB (1982) Mineralization of organic matter in the sea bed - the role of sulphate reduction. Nature 296: $643-645$

Jørgensen BB (1994) Sulfate reduction and thiosulfate transformations in a cyanobacterial mat during a diel oxygen cycle. FEMS Microbiol Ecol 13:303-312

Jørgensen NOG, Blackburn TH, Henriksen K, Bay D (1981) The importance of Posidonia oceanica and Cymodoces nodosa as contributors of free amino acids in water and sediment of seagrass beds. PSZN I: Mar Ecol 2:97-112

King $G$ (1988) Patterns of sulfate reduction and the sulfur cycle in a South Carolina salt marsh. Limnol Oceanogr 33: $376-390$

Koepfler ET, Benner R, Montagna PA (1993) Variability of dissolved organic-carbon in sediments of a seagrass bed and an unvegetated area within an estuary in Southern Texas. Estuaries 16:391-404

López NI, Duarte CM, Vallespinós F, Romero J, Alcoverro T (1995) Bacterial activity in NW Mediterranean seagrass (Posidonia oceanica) sediments. J Exp Mar Biol Ecol 187 . $39-49$

McRoy CP, Mc Millian C (1977) Production ecology and physiology of seagrasses. In: McRoy $C P$. Helfferich $C$ (eds) Marine science, Vol 4, Seagrass ecosystems. Marcel

Editonal responsibiluty: Tom Fenchel, Flelsinger, Denmark
Dekker, Inc, New York, p 53-87

Moriarty DJW, Boon PI, Hansen JA, Hunt WG, Poiner IR, Pollard PC, Skyring GW, White DC (1985) Microbial biomass and productivity in seagrass beds. Geomicrobiol J 4:21-51

Moriarty DJW, Iverson RL, Pollard PC (1986) Exudation of organic carbon by the seagrass Halodule wrightii and its effect on bacterial growth in the sediment. J Exp Mar Biol Ecol 96:115-126

Moriarty DJW, Roberts DG, Pollard PC (1990) Primary and bacterial productivity of tropical seagrass communities in the Gulf of Carpentaria, Australia. Mar Ecol Prog Ser 61: $145-157$

Norusis MJ (1.993) SPSS for windows. Base system user's guide, release 6.0. SPSS Inc, Chicago

Oremland RS, Taylor BF (1977) Diurnal fluctuations of $O_{2}, N_{2}$, and $\mathrm{CH}_{4}$ in the rhizosphere of Thalassia testudinum. Limnol Oceanogr 22:566-570

Penhale PA, Smith WO (1977) Excretion of dissolved organic carbon by eelgrass (Zostera marina) and its epiphytes. Limnol Oceanogr 22:400-407

Pollard PC, Koike I, Mukai H, Robertson AI (eds) (1993) Tropical seagrass ecosystems; structure and dynamics in the Indo-West Pacific. Aust J Mar Freshwat Res 44

Pollard PC, Moriarty DJW (1991) Organic-carbon decomposition, primary and bacterial productivity, and sulfate reduction, in tropical seagrass beds of the Gulf of Carpentaria, Australia. Mar Ecol Prog Ser 69:149-159

Sand-Jensen K, Prahl C, Stokholm H (1982) Oxygen release from roots of submerged aquatic macrophytes. Oikos 38: 349-354

Smith RD, Dennison WC, Alberte RS (1984) Role of seagrass photosynthesis in root aerobic processes. Plant Physiol 74: $1055-1058$

Sorokin YI (1962) Experimental investigation of bacterial sulfate reduction in the Black Sea using ${ }^{35} \mathrm{~S}$. Microbiology 31: 329-335

Thayer GW, Wolfe DA, Williams RB (1975) The impact of man on seagrass systems. Am Sci 63:288-296

Welsh DT, Bourgués $S$, de Wit $R$, Auby I (1997) Effect of plant photosynthesis, carbon sources and ammonium availability on nitrogen fixation rates in the rhizosphere of Zostera noltii. Aquat Microb Ecol 12:285-290

Wetzel RG, Penhale PA (1979) Transport of carbon and excretion of dissolved organic carbon by leaves and roots/rhizomes in seagrasses and their epiphytes. Aquat Bot 6 : $149-158$

Zimmerman RC, Cabello-Pasini A, Alberte RS (1994) Modeling daily production of aquatic macrophytes from irradiance measurements: a comparative analysis. Mar Ecol Prog Ser 114:185-196

Submitted: September 17. 1997; Accepted:December 29, 1997 Proofs received from author(s): March 20, 1998 